\title{
Club-based format of teaching Russian as foreign language to Chinese students
}

\section{Formato baseado em clube de ensino de russo como língua estrangeira para estudantes chineses}

\section{Formato basado en clubes para enseñar ruso como lengua extranjera a estudiantes chinos}

\author{
Svetlana Yrievna Zalutskaya iD
}

M.K. Ammosov North-Eastern Federal University, Yakutsk, Russian Federation.

Corresponding author:

Svetlana Yrievna Zalutskaya

Email: zs-saha@mail.ru

How to cite: Zalutskaya, S. Y. (2021). Club-based format of teaching Russian as foreign language to Chinese students. Revista Tempos e Espaços em Educação, 14(33), e15526. http://dx.doi.org/10.20952/revtee.v14i33.15526

\begin{abstract}
The study deals with the issue of applying the communicative club format for organizing leisure, educational, and cultural activities for foreign students interested in the Russian language. The authors describe the structural and content model of the Almaz Russian-language Russian-Chinese communication club created based on centers for the Russian language, literature, and culture at the Ammosov North-Eastern Federal University. The model includes target, technological, and content components and implementation mechanisms. The authors conclude that interactive technologies of leisure show great potential for developing foreign students' communicative competence and creative abilities and enriching the individual with knowledge about the traditional culture of peoples inhabiting the multicultural territory of Russia.
\end{abstract}

Keywords: Club-based technologies. Federal university. Learning. Regional component. Russian as a foreign language.

\section{RESUMO}

O estudo trata da questão da aplicação do formato de clube comunicativo para a organização de atividades recreativas, educacionais e culturais para estudantes estrangeiros interessados na língua russa. Os autores descrevem o modelo estrutural e de conteúdo do clube de comunicação russochinês de língua russa Almaz, criado com base nos centros de língua, literatura e cultura russas da Universidade Federal do Nordeste Ammosov. O modelo inclui componentes de destino, tecnológicos e de conteúdo e mecanismos de implementação. Os autores concluem que as tecnologias interativas de lazer apresentam grande potencial para desenvolver a competência 
comunicativa e as habilidades criativas de estudantes estrangeiros e enriquecer o indivíduo com o conhecimento sobre a cultura tradicional dos povos que habitam o território multicultural da Rússia. Palavras-chave: Aprendendo. Componente regional. Russo como língua estrangeira. Tecnologias baseadas em clube. Universidade federal.

\section{RESUMEN}

El estudio aborda el tema de la aplicación del formato de club comunicativo para la organización de actividades lúdicas, educativas y culturales para estudiantes extranjeros interesados en la lengua rusa. Los autores describen el modelo estructural y de contenido del club de comunicación rusochino en idioma ruso de Almaz creado en base a los centros de lengua, literatura y cultura rusas en la Universidad Federal del Nordeste de Ammosov. El modelo incluye componentes de destino, tecnológicos y de contenido y mecanismos de implementación. Los autores concluyen que las tecnologías interactivas del ocio muestran un gran potencial para desarrollar la competencia comunicativa y las habilidades creativas de los estudiantes extranjeros y enriquecer al individuo con conocimientos sobre la cultura tradicional de los pueblos que habitan el territorio multicultural de Rusia.

Palabras clave: Aprendiendo. Componente regional. Ruso como lengua extranjera. Tecnologías basadas en clubes. Universidad federal.

\section{INTRODUCTION}

The process of globalization, encompassing education, intensifies cross-cultural contacts while a communicative club as an environment for a multi-level dialogue of cultures and a space for the implementation of interactive educational technologies has significant pedagogical potential in the system of forming cross-cultural competence. A communicative club allows transitioning to an initiative-based and developing model of the recreational form of education, offering great opportunities for: a) comprehensive cognition in a dialogue mode of another culture in all the diversity of its manifestations; b) the inclusion of the acquired knowledge about other people's language and culture in the context of interpersonal communication and the transformation of this knowledge into an element of the linguistic picture of the world; c) formation of an individual thesaurus, as well as universal cognitive structures and communicative competences, by each member of the club; d) dynamic and productive comparison of specific cultural and linguistic experiences.

Ultimately, all this contributes to the formation of the club members' communicative competence and, at the same time, allows applying the competence in various forms of club activities. Therefore, researchers characterize clubs as a form of organizing and spending leisure time for educational purposes as an independent, individual-group, thematic, and dialogue-based (Novikov, 2006, p. 27) form of open education. Club-based education is popular not only in Russia (Aksenova, 2020; Bukhtiarova, 2020; Dergaeva, 2017; Druzhinina, 2018; Tregub, 2017) but also in the education systems of different countries. Such education has its traditions, for example, in Japan. Japanese schoolchildren, students, and young people strive not only to take advantage of their leisure time and acquire new competences but also to find friends and enjoy communication. Club meetings in Japan are "an important component of general secondary school education as a social institution" (Machekhina, 2017, p. 39) and provide an alternative to standardized schooling, a platform for educating people "with creative abilities and spontaneous energy" (Tanikawa, 2003). In China, clubs are mostly associated with the comprehensive development of students' personalities in "interest groups". Thus, "according to a 2019 survey organized by the Chinese Ministry of Education, nearly $87 \%$ of students received art education in elementary and secondary schools and $65 \%$ of students participated in art clubs or other interest groups" (CGTN, 2019). For Chinese students and schoolchildren, a club is an opportunity for creative self-fulfillment which 
children do not have when studying at school or university since traditionally "the Chinese education system as a whole seriously limits students' creative abilities and individuality" (Khlystov, 2016) and is based on knowledge approach and reproductive teaching methods. However, the modern Chinese education system is open to new forms of education and supports innovative approaches to organizing classes for better results so the club form of education is becoming increasingly popular. The most important thing in this form of education is the organization of an event in which students' self-fulfillment takes place.

Considering the difference in the interpretation of educational club activities by Russian and foreign researchers, the study is based on a universal definition that describes the club features relevant for the modern global educational space:

[...] this is an educational association of like-minded students created for teaching, upbringing, communication, joint activities, and leisure of children united by scientific, artistic, sports, or other interests and their comprehensive development and self-fulfillment. Clubs have the following features: voluntary membership, elements of self-government (general meeting, council), unity of purpose, intimacy, club symbols and attributes (name, motto, song, uniform, emblem, badge) (Torshina, 2017, p. 13).

The researcher extends the interpretation of the basic concept to only one category of students - children. However, the educational practice has proven the legitimacy and efficiency of club education for people of different ages, training levels, and interests, including language learning. Therefore, another feature of club education should be identified - the chance to organize "language learning cooperation" by the club members united by "the desire to comprehend a foreign-language culture and consciously learn lexical constants" and the optional attendance of all classes aimed at the formation of students' linguistic base "of the target language combined with the cultural component" (Shapovalova, 2014, p. 722).

These features manifested in the operations of the Almaz Russian-Chinese club for communication in Russian created in November 2020 based on centers for the Russian language, literature, and culture at the Ammosov North-Eastern Federal University (NEFU). The centers operate at universities in the northeast of the People's Republic of China (PRC). The operations aim to strengthen international positions and promote the Russian language and educational programs in Russian in the northeast PRC. The authors of the project focused their efforts on achieving the following goals: a) strengthening the role of the Russian language and educational programs in Russian in the northeast of the PRC; b) support for studying and teaching the Russian language at Chinese universities; c) improving the professional online distance learning platform "Russian studies at the NEFU".

At the initial stage of its implementation, the project to create a communication club in Russian required developing a theoretical model for this form of teaching foreign students. The model should consider the conditions of leisure and educational activities aimed to promote the Russian language outside of Russia. The social and public significance of the model for the implementation of the Almaz Russian-language Russian-Chinese communication club in the context of interuniversity Russian-Chinese educational relations in modern conditions consists in popularizing the Russian language and educational programs in Russian for foreign students, as well as creating an open educational environment, contributing to the acculturation of Chinese students (Anderson \& Guan, 2017; Zhu, 2016), their adaptation in a foreign-language cultural space, increasing their interest in studying the Russian language, literature, culture, and history, and improving the scientific and educational-methodological base of learning Russian as a foreign language (RFL).

The achievement of these goals is associated with solving the following tasks: a) to develop the format for a club for communicating in Russian on the Internet for student youth and RFL 
teachers in the northeast of PRC; $b$ ) to develop teaching and methodological educational materials for the NEFU Centers for the Russian language, literature, and culture, considering national features and stimulating interest in Russian education, culture, and science; $c$ ) to make a list of topics and develop the curriculum and work schedule; d) to organize meetings of the Russian-Chinese club for communication in Russian; d) to organize information support for the Russian-Chinese club for communication in Russian.

\section{METHODOLOGY}

We utilized theoretical analysis and synthesis of research carried out earlier in line with the topics tested at international scientific and practical conferences and forums. We used the results, tools, and capabilities of previous scientific and practical projects at the NEFU, supported in different years by grants from the Ministry of Education of the Russian Federation (RF) and the Russkiy Mir Foundation: "Linguodidactic online resource "Russian studies at the NEFU" (2017), "Asia-Pacific Online School of Russian Studies: Innovative Practices (2018), International Forum "Russian Studies in Russia and China: Innovative Practices" (2018, 2019, Yakutsk, Harbin), "The Network of NEFU Centers for Russian Language, literature, and culture in Chinese universities" (2019).

We carried out diagnostic studies: questionnaires, interviewing, testing; observational studies (participant observation, performance study); modeling.

\section{FRAMEWORK OF THE STUDY}

The implementation framework of the model of the Almaz Russian-Chinese club for communication in Russian: a network of centers for the Russian language, literature, and culture at the universities in the northeast of the PRC, which were opened by the NEFU in 2019.

If one follows the activities of the NEFU in the field of promoting the methodology of RFL in the northeast of the PRC, there is a growing trend of various bilateral cooperation formats: a) agreements have been made with 15 universities in the northeast of the PRC and three NEFU Centers for the Russian language, literature, and culture have been created in partner universities, which accumulate Chinese students and teachers interested in the Russian language, literature, and culture and can serve as an excellent base for the project; b) the practice of holding regular international scientific and practical conferences and forums has been established (since 2013, two forums and three conferences have been held), collections of scientific works by Yakut researchers have been published, and joint basic educational programs have been introduced. Since 2015, days of the Russian language and literature have been held annually at PRC universities, including educational events, competitions, and contests.

The Almaz Russian-Chinese club for communication in Russian based on the network of NEFU centers for the Russian language, literature, and culture at universities in the northeast of the PRC is the way of working with Russian studies communities in the northeast of the PRC where the interest in Russian is only increasing.

The Russian-Chinese club for communication in Russian operates online. The curriculum includes seven thematic session meetings. The topics of the meetings contribute to the gradual development of the linguistic sociocultural and communicative competences in Chinese students.

\section{RESULTS}

The results of studying the potential of the club form of organizing teaching RFL to foreign students: a) we described the phenomenon of club-based (leisure) online activities as a relevant format of cross-cultural communication in the context of a dialogue of cultures and developed a model for the implementation of a communication club in Russian to form the communicative competence of its foreign language participants; b) we identified the educational opportunities of a 
club as a communicative-oriented microenvironment, serving as a leisure and educational system; c) we substantiated the culture-centric orientation of the interactive activity of foreign language members of a club as an educational basis for optimizing the conditions for the formation of their communicative competence and personal growth; d) we formulated the principles for optimization of communicative competence formation in a club association of linguistic and cultural orientation ensuring the methodological soundness and efficiency of the leisure-educational process; e) we developed a concept for the actualization of the communicative potential of the members of a linguocultural club as a form and means of personality-oriented formation of communicative competence, carried out continuously and comprehensively in the system of additional education based on interactive forms of organizing joint activities for a foreign language target audience.

During the study, we determined the theoretical significance of the developed and tested in practice structural and content model of the club form of teaching Russian to Chinese students: a) we gave an original interpretation of the club (leisure) online activity as an activity-oriented and practice-oriented system in the unity of cognition and practical participation of the individual in optimizing cross-cultural dialogue in Russian in the context of online leisure and educational space; b) we identified the socio-public potential of a linguoculturally-oriented club as an efficient form of fostering a culture of dialogue in Russian. The capabilities of this form are determined by the ability of leisure, educational, and cultural activities to functionally and meaningfully supplement and expand the conditions for the development and self-actualization of foreign-language club members. The social and public significance of the model of the Almaz Russian-Chinese club for communication in Russian in the context of interuniversity Russian-Chinese educational relations in modern conditions is to popularize the Russian language and educational programs in Russian for foreign students, as well as create an open educational environment, contributing to the development of interest among foreigners in studying the Russian language, literature, culture, and history, in improving the scientific, educational, and methodological basis of RFL teaching; c) we characterized the self-realization capabilities of interactive technologies for organizing leisure, educational, and cultural activities in the conditions of a club; d) we developed the concept of a Russian-Chinese club for communication in Russian as a multicultural community and a multifunctional leisure-educational environment that created additional opportunities for selfactualization and compensated for the lack of conditions for the formation of communicative competence in other spheres of foreign-language members of the club; e) we created a model of Russian-Chinese communication that makes it possible to build leisure, educational, and cultural activities in Russian in the online space based on a dialogue of cultures using interactive technologies in a club.

\section{DISCUSSION}

The development of a structural and content model of a communicative club for communication in Russian for Chinese students began with a description of the concept of its creation, defining its features.

Basic principles of the Concept for creating the Almaz Russian-Chinese club for communication in Russian based on the network of NEFU centers for the Russian language, literature, and culture at universities in the northeast of the PRC: a) the Almaz Russian-Chinese club for communication in Russian was formed based on the NEFU; b) the club is a permanent platform for communication, getting acquainted with the culture of the northeast of Russia, and the development of educational programs in Russian, presentations of joint scientific, and methodological projects of RFL teachers and philology students from China and Russia; c) the club is an open interface for partnerships between universities in the field of RFL; $d$ ) the club creates an opportunity for the professional development of RFL teachers and students of Chinese universities; 
e) the club is a presentation (showcase) and replication platform for best practices in the field of RFL.

For the functioning of the Almaz Russian-Chinese club of communication in Russian, NEFU resources were used: the team, infrastructure, linguistic and methodological developments, the reputation of the university in the northeast of the PRC, professional relations with the community of Russian specialists in the countries of the Asia-Pacific region (APR).

The focus of the work of the Almaz Russian-Chinese club for communication in Russian is the presentation of innovative developments by RFL teachers who have many years of experience in the APR, as well as the formation of students' communicative competence.

The Russian-Chinese club for communication in Russian is a platform for professionals in the field of RFL with extensive practical experience in foreign countries, mainly in the APR, to demonstrate and broadcast innovative technologies and successful practices. Moreover, at club meetings, an image of Russia is created as a country where one wants to study.

All meetings of the Russian-Chinese club are accompanied by workshops on linguistic and cultural topics. Club members, including teachers and students - Chinese philologists, acquire new competences, improve their professional qualifications, and improve as project leaders in RFL.

Practical approbation of the model of the Russian-Chinese communication club was carried out in the format of online broadcasting of meetings from 12 Nov. to 24 Dec. 2020.

The structural and content model of the Almaz Russian-Chinese club for communication in Russian (based on the NEFU centers for the Russian language, literature, and culture at universities in the northeast of the PRC)

Today, to ensure the sustainable development of the centers for the Russian language, literature, and culture of the NEFU, opened in 2019 with the support of the Ministry of Education of the Russian Federation, as well as to increase the popularity of the Russian language among Chinese students, a new format of an interactive communication platform is required. Such a form of communication is a club for communication in Russian which is designed to organize an educational extracurricular leisure-educational process in a digital environment on the online platform "Russian studies at the NEFU". The structural and content model of an open education center for studying Russian and in Russian based on an interest club among professional and specialized communities clearly illustrates the interactive nature of club-based learning.

Members of the multimedia communication club participate in informal meetings (sessions) organized by the teacher-moderator in their free time from the main classes, get an additional opportunity to develop their communication skills and public speaking skills in Russian, and gain new knowledge about the culture of Russia and Yakutia as the largest and the most unique multicultural subject of the Russian Federation. The target audience, including RFL teachers from the northeast of China, students, and everyone interested in the Russian language, at club meetings develops the ability to communicate in Russian in the context of a dialogue of cultures, expand their cultural horizons, and discover an attractive image of Russia and its northern regions. The club as a leisure and educational platform also helps RFL teachers from Chinese universities in organizing extracurricular activities in the field of language practice, enriching vocabulary.

Interactive technologies used by the team of authors include technologies for organizing club activities, game technologies, case technologies, multimedia technologies, technologies for social and cultural creativity, and technologies for the artistic organization of leisure, educational, and cultural activities: conversations, games, creative competitions, debates, holidays, cross-cultural training sessions, theatrical performances, visiting meetings, etc. The methods used include the project method, the dialogue method, visual methods, and methods of artistic influence. The means of club activity in the formation of the communicative competence of an individual are the living word, various types of art (theater, cinema, animation, painting, literature), technical and visual aids (illustrations, books, video materials, drawings), and the media. 
The practice of promoting the Russian language and educational programs in Russian in the northeast of the PRC (in the provinces of Heilongjiang, Jilin, Liaoning, and others) has shown a clear trend of increasing interest in Russian studies and Russian language, literature, and culture and the popularity of Russian education among young people in border regions. Based on this, the problem of club-based education to be solved is to activate communicative competences among members of the club, maintain interest in the Russian language, help RFL teachers of Chinese universities with extracurricular activities in the field of language practice, and form an attractive image of Russia and Yakutia as a multicultural region of the RF. To solve the problem, we created the Almaz RussianChinese club for communication in Russian based on the network of NEFU centers for the Russian language, literature, and culture at universities in the northeast of the PRC and developed and tested a model for its implementation.

Form of education: distance. The leisure and educational program of the club is focused on improving communicative competences, practical knowledge, and skills in the field of the Russian language, culture, and literature and regional studies of Russia, considering the cultural and national features of the Chinese audience.

Target audience: students from the Russian Language Institute at the Heilongjiang University, the Changchun University of Science and Technology, the Heilongjiang Institute of Foreign Languages, the Jilin University, the Jilin Normal University, the Qiqihar University, the Harbin Normal University, the Harbin Polytechnic University, the Harbin University of Science and Technology, the Dalian University of Technology, the Anshan Normal University, the East University of Heilongjiang (estimated number of participants - over 100).

Within the framework of the signed agreements, the NEFU cooperates with the universities of the PRC: the East University of Heilongjiang has an agreement on the joint education for students for the double diploma program. Among the recent and most successful achievements in the field of bilateral educational cooperation is an increase in the number of exchange programs between the NEFU and Chinese universities, the creation of a linguodidactic online resource on the university's website "Russian studies in the in the North-East of Russia and the APR countries" (2017), creation of three NEFU Russian Language, Literature, and Culture Centers at the Changchun University of Science and Technology (2018), the East University of Heilongjiang and the Jilin Normal University (2019), holding annual bilateral international forums "Russian studies in Russia and China: Innovative Practices "(2018, 2019), the organization of the "NEFU Weeks of the Russian Language and Culture" which have been held at high schools in the PRC since 2015 with high frequency.

The club meeting schedule consists of seven self-sufficient modules - sessions of the communication club for Chinese and Russian students and specialists in Russian studies. Each module includes an extensive roster of relatively independent teaching and educational topics.

Factors influencing the formation of an efficient club-based communicative educational environment of the Almaz Russian-Chinese club for communication in Russian: a) the first is associated with the creation of interactive communicative leisure and educational environment; $b$ ) the second refers to educational content and implies filling the club educational environment with relevant communicative content; c) the third is associated with the means of intercultural communication, represented by game-based methods and group forms of organizing communicative leisure and educational environment. Games are the most popular interactive form of leisure and educational activities for forming communicative competence in a foreign language audience. Games in the club take place in an experimental situation. Games are characterized by both convention and seriousness. The competitive aspect helps the club members to solve their problems and role-based imitation actualizes the development of the communicative competence of the club members; d) the fourth defines a foreign student as an active subject of communicative leisure and educational environment and actualizes the student's communicative competences; e) 
the fifth refers to the presenter (speaker or moderator) and is associated with the creation of specially organized situations of club communication.

The club-based communicative leisure-educational environment is interpreted as a set of leisure conditions that provide foreign students with the implementation of educational communication activities based on the integration of specially selected means of cross-cultural communication and educational information. The most important characteristic of the communicative leisure and educational environment which is created in the Russian-Chinese club for communication in Russian, are the ideas of humanization, identity, and integration.

The considered essential features of a communicative leisure-educational environment determine the specifics of the structural-content model of the Almaz Russian-Chinese club for communication in Russian (based on the network of NEFU centers for the Russian language, literature, and culture at universities in the northeast of the PRC) to form the communicative success of foreign students in the context of the dialogue of cultures (Figure 1).

Figure 1. The model of the Almaz Russian-Chinese club for communication in Russian based on the network of NEFU centers for the Russian language, literature, and culture at universities in the northeast of the PRC.

\section{Model components}

\section{Principles for organizing the club-based communicative leisure and educational environment}

\begin{tabular}{|c|c|c|c|c|}
\hline Humanization & Openness & Dialogical basis & $\begin{array}{c}\text { Cultural } \\
\text { orientation }\end{array}$ & Integration \\
\hline
\end{tabular}

Didactic principles of club-based communicative activities

\begin{tabular}{c|cc|c|}
\hline & Didactic principles of club-based communicative activities \\
\hline $\begin{array}{c}\text { Involvement of } \\
\text { Chinese students in } \\
\text { club activities }\end{array}$ & $\begin{array}{c}\text { Stimulating educational } \\
\text { communication activities }\end{array}$ & $\begin{array}{c}\text { Club members becoming } \\
\text { familiar with the position of an } \\
\text { active participant in club } \\
\text { meetings }\end{array}$ & $\begin{array}{c}\text { Implementation of the } \\
\text { program and } \\
\text { methodological support } \\
\text { of club activities }\end{array}$ \\
\hline
\end{tabular}

\section{Club communication format}

Online communication that utilizes the potential of the platform "Russian studies at the NEFU"

Technological component

technologies for organizing club activities, game-based technologies, multimedia technologies, technologies for social and cultural creativity, technologies for artistic organization of leisure, educational and cultural activities: conversations, games, creative competitions, debates, holidays, cross-cultural trainings, theatrical performances, visiting meetings, etc.

$\begin{array}{cccccc}\begin{array}{c}\text { Conversations, } \\ \text { discussions, }\end{array} & \text { Discussing special } & \text { Project } & \text { Creative } & \text { Comparative skills. } & \text { Preparation of } \\ \text { opinion exchange } & \text { literature. Discussing } & \text { activities, } & \text { contests. } & \text { Analytical skills. } & \text { speeches, } \\ & \text { films and identifying } & \text { training } & \text { Acting } & \text { Observation skill. } & \text { presentations } \\ & \text { cultural } & \text { sessions, } & \text { training } & \text { Mind games } & \\ & \begin{array}{c}\text { phenomenology. } \\ \text { Discussing fiction. }\end{array} & \begin{array}{c}\text { educational } \\ \text { games }\end{array} & \text { sessions } & & \\ & & & \end{array}$

Content component 
Seven thematic modules:

1. Introducing the M.K. Ammosov NEFU.

2. Hello, Yakutia!

3. National cuisine in the land of permafrost: tasty, healthy, tested for centuries, clean food of Yakutia.

4. Gemstones of Yakutia.

5. Folk tales of Permafrost.

6. Winter starts from Yakutia.

7. Celebrating the Russian language.

\title{
MECHANISMS FOR MODEL IMPLEMENTATION
}

\author{
Objectives: \\ - strengthening the role of the Russian language and educational programs in Russian in the northeast of the PRC; \\ - support for the study and teaching of the Russian language in the universities of the PRC; \\ - improvement of the professional online distance platform "Russian studies at the NEFU". \\ Goals: \\ - develop the club format for communication in Russian on the Internet for student youth, teachers of RFL in the northeast of the \\ PRC; \\ - develop educational and methodological educational materials for the Centers of the Russian language, literature and culture \\ at the NEFU, taking into account national specifics and stimulating interest in Russian education, culture and science; \\ - form a list of topics, develop a program and schedule of the club; \\ - organize meetings of the Russian-Chinese club for communication in Russian; \\ - organize information support for the Russian-Chinese club for communication in Russian
}

\section{Target audience:}

students from the Russian Language Institute at the Heilongjiang University, the Changchun University of Science and Technology, the Heilongjiang Institute of Foreign Languages, the Jilin University, the Jilin Normal University, the Qiqihar University, the Harbin Normal University, the Harbin Polytechnic University, the Harbin University of Science and Technology, the Dalian University of Technology, the Anshan Normal University, the East University of Heilongjiang (over 100 participants).

\section{Technical requirements:}

platforms "Voov" or "Zoom" for classes and online conferences.

The NEFU website

\section{Conditions:}

- involvement of club members in interactive activities;

- a variety of forms of activity for the club members: culturally oriented, cognitive and creative, practice-oriented;

- taking into account the cultural and national characteristics of the target audience;

- attraction of foreign students at the federal university to the organization of the club;

- inclusion of the national-regional component in the educational content;

- inclusion of club members in the actual ethno-cultural life of the region;

- motivation of club members with a bonus program

\section{Implementation stages of the model for the Russian-Chinese club for communication in Russian:}

1. Organizational stage: building a project team; identifying resources and drawing up a work plan; development of the Charter and corporate identity of the club, the layout of the club card; creating a work plan for the club; developing the layout for an information letter and an invitation to cooperation of Chinese partner universities; selecting an international electronic platform - a social network for broadcasting videoconferences in real time that would be available in China.

2. Organizational and methodological stage: planning club meetings; accumulation of educational and methodological multimedia materials, taking into account the cultural and national characteristics of the target audience.

3. Information stage: replication of advertising and informational materials through all possible channels available in China (social networks, e-mail, websites of the NEFU and partner universities of the PRC).

4. Stage of implementation: organization of seven meetings of the club for open communication in Russian.

5. Analytical stage: analysis of the results of the implementing the model of the Russian-Chinese club of communication in Russian and preparation of reporting documentation.

The content of the club meetings (Table 1) considers the specifics of the target audience, the cultural context of the selected topics, dialogue, and game-based approaches in organizing meetings. The homework for the club members is obligatory: the members do their homework independently (for example, learning a song in Russian, writing a recipe for their favorite Chinese 
dish, preparing a presentation and a story about their university, learning by heart a poem by a Russian poet, preparing a story about their favorite folk tale hero, creating a drawing "My Russian language", and others), the quality of which is stimulated by the bonus program (prizes, diplomas, certificates for competition winners).

Table 1. The syllabus of sessions at the Almaz Russian-Chinese club for communication in Russian based on the network of NEFU centers for the Russian language, literature, and culture at universities in the northeast of the PRC.

\begin{tabular}{|c|c|c|c|}
\hline No. & Sessions & Topics & $\begin{array}{l}\text { Number of } \\
\text { hours: } 36\end{array}$ \\
\hline 1 & $\begin{array}{l}\text { Opening of the Almaz } \\
\text { Russian-Chinese club for } \\
\text { communication in Russian } \\
\text { (based on the network of } \\
\text { NEFU centers for the Russian } \\
\text { language, literature, and } \\
\text { culture at universities in the } \\
\text { northeast of the PRC) }\end{array}$ & $\begin{array}{l}\text { Topic 1. Introducing the M.K. Ammosov NEFU. } \\
\text { Topic } 2 \text {. Teacher of RFL. Our graduates. } \\
\text { Topic 3. Presentation of the Almaz Russian-Chinese } \\
\text { club of communication in Russian }\end{array}$ & $\begin{array}{l}2 \text { (meeting) }+4 \\
\text { (homework) }\end{array}$ \\
\hline 2 & Hello, Yakutia! & $\begin{array}{l}\text { Topic } 1 . \text { Online quiz "Unique region: the power and } \\
\text { strength of nature." } \\
\text { Topic } 2 \text {. Video lesson "Tourist brands of Yakutia: Lena } \\
\text { Pillars, the Kingdom of Permafrost, the Pole of Cold, } \\
\text { Buluus, etc.!" } \\
\text { Topic 3. Workshop in Russian: graphic-symbolic } \\
\text { analysis of the text }\end{array}$ & $\begin{array}{l}2 \text { (meeting) }+4 \\
\text { (homework) }\end{array}$ \\
\hline 3 & $\begin{array}{l}\text { Visiting the Russian Language } \\
\text { Institute at the Heilongjiang } \\
\text { University. } \\
\text { National cuisine of Yakutia } \\
\text { and China. }\end{array}$ & $\begin{array}{l}\text { Topic } 1 . \text { Virtual tour of the culinary map of Yakutia } \\
\text { "National cuisine in the land of permafrost: tasty, } \\
\text { healthy, tested for centuries, clean food of Yakutia." } \\
\text { Topic } 2 \text {. Video lesson "Meat, fish, berries, milk. From } \\
\text { the history of words and expressions." } \\
\text { Topic 3. Workshop in Russian: preparing breakfast } \\
\text { together }\end{array}$ & $\begin{array}{l}2 \text { (meeting) }+4 \\
\text { (homework) }\end{array}$ \\
\hline 4 & $\begin{array}{l}\text { Visiting the Jilin Normal } \\
\text { University. } \\
\text { Gemstones of Yakutia and } \\
\text { China. }\end{array}$ & $\begin{array}{l}\text { Topic 1. Video lesson "Yakut jewelry: diamonds, gold, } \\
\text { silver, platinum, jade, chrome diopside, charoite, etc. } \\
\text { History of discoveries." } \\
\text { Topic 2. Workshop in Russian "Gemstones of China". } \\
\text { Topic 3. Workshop in Russian: creating a handmade } \\
\text { bracelet in the Yakut style }\end{array}$ & $\begin{array}{l}2 \text { (meeting) }+2 \\
\text { (homework) }\end{array}$ \\
\hline 5 & $\begin{array}{l}\text { Visiting the Changchun } \\
\text { University of Science and } \\
\text { Technology. } \\
\text { Folk tales of Yakutia and } \\
\text { China. }\end{array}$ & $\begin{array}{l}\text { Topic 1. Readers' conference "Tales of Permafrost and } \\
\text { the Celestial Empire". } \\
\text { Topic } 2 \text {. Video lesson "Russian and Yakut fairy tales in } \\
\text { the Arctic Circle". } \\
\text { Topic } 3 \text {. Workshop in Russian: making a book trailer } \\
\text { based on folk tales from Russkoye Ustye }\end{array}$ & $\begin{array}{l}2 \text { (meeting) }+4 \\
\text { (homework) }\end{array}$ \\
\hline 6 & Holidays in Yakutia and China & $\begin{array}{l}\text { Topic 1. Video lessons "Winter begins in Yakutia", } \\
\text { "Yhyakh. The holiday welcoming summer and the } \\
\text { awakening of nature". } \\
\text { Topic 2. Presentation of the summer and winter } \\
\text { holidays in China. } \\
\text { Topic 3. Workshop in Russian: drawing Ded Moroz } \\
\text { together // drawing the New Year together. Guided } \\
\text { tour of the exhibition of drawings }\end{array}$ & $\begin{array}{l}2 \text { (meeting) }+4 \\
\text { (homework) }\end{array}$ \\
\hline 7 & $\begin{array}{l}\text { The evening of the Russian } \\
\text { language }\end{array}$ & $\begin{array}{l}\text { Celebration of the Russian language (based on a } \\
\text { separate program). } \\
\text { Workshop in Russian: reading poetry together. } \\
\text { Initiation for new club members }\end{array}$ & 2 (meeting) \\
\hline
\end{tabular}


An expert group of RFL students and teachers in the PRC was working during the implementation of this model of a communication club in Russian for Chinese students. There were three experts. The purpose of the examination is to assess the success of the work of the Almaz club, its shortcomings, as well as the prospects for implementing this form of organizing leisure, educational, and cultural activities of Chinese students interested in the Russian language.

The main conclusions of the expert group: "Throughout all the meetings, the club was attended by many excellent students and teachers who interestingly taught the Russian language and made speeches, fully expressing their sincerity and attention. Moreover, during the meetings, fearing that many students would not understand something in Russian, wherever they are, the teachers showed PPTs with Russian and Chinese translations and used them simultaneously, fully respecting students. And there were many interactive sessions and Q\&As, competitions, games that were very new and interesting... The club will broaden and activate students' deep cultural memory... Russian songs and poems make all meetings a lively and interesting practice in the Russian language... There are difficulties with the Internet... Chinese students have acquired knowledge and are in a good mood... We want to meet without the online component... We wish to continue meeting in the club".

\section{CONCLUSION}

The expert opinion, the results of testing the structural and content model of the Almaz Russian-Chinese club for communication in Russian based on the network of NEFU centers for the Russian language, literature, and culture at universities in the northeast of China made it possible to conclude its productivity and readiness for practical application for teaching RFL to Chinese students. Its efficiency is determined by: a) the considerable educational potential of the club association as an environment for developing the communicative competence of foreign language community members; b) the productivity of interactive technologies of leisure, educational, and cultural activities as a resource for developing the club members' communication skills in the context of the dialogue between the cultures of China and the northern Russian region; $c$ ) the logic of the mechanism for implementing the developed model.

The club association acts as a kind of microenvironment for communication, in which the individual finds sources of meeting certain needs. Students come to the club, guided by both instrumental and affective motives. There is no language teaching in the club but language practice takes place, which is the instrumental motive for the individual to join the club. Moreover, the club creates an atmosphere that cannot be created elsewhere; the student is immersed in Russian culture, traditions, artistic styles, etc. Interactive technologies of leisure, educational, and cultural activities, carried out in the club based on cultural dialogue, have great potential for developing not only communicative competence but the foreign language student's creative abilities and enriching them with knowledge about the traditional culture of peoples inhabiting the multicultural space of Russia. Exchange of information with members of another culture forms the knowledge of social groups about their own and other cultures and skills of intercultural interaction.

To enrich the cultural potential of the club, adhere to the principle of diversity of speechbehavioral strategies, it is advisable to take trips across the territory of the multicultural and multilingual region of the RF. Participants have the chance to apply their knowledge and skills in the environment of folk culture.

All types of dialogue on the club's online platform contribute to the formation of comparative and analytical skills of the target audience. The club format allows students to practice communicative and cross-cultural competences and stimulates the development of their conative and affective components. Project work and preparation of speeches and presentations for club meetings actualize the types of knowledge that are part of the communicative competence in foreign-language members of the club. 
The club form of operation allows students to create their portfolio for the development of communicative competence and consciously manage its development.

There are some technological aspects to developing the communicative competence in foreign language members of the Russian language club: a) communication in the club is exclusively in Russian; b) organization of club conversations on linguistic and cultural topics; $c$ ) the creation of new traditions for the team, contributing to the development of communicative and cross-cultural competences; d) involvement of theatrical performances and acting training sessions in Russian; e) stories about cultural events in Russian; f) holding special events to increase the level of communicative and cross-cultural competence of club members who are interested in and want to learn Russian during their leisure time; g) organization of holidays, intellectual and creative competitions.

Therefore, when organizing the work of the club, one should observe the following conditions to achieve the goals and objectives of the Russian-Chinese club of communication in Russian: a) ensure a real dialogue of cultures in the organization of leisure and educational activities for club members; b) stimulate the cognitive activity of members of the club association by using interactive forms that develop cognitive, affective, and conative aspects of the personality; c) manage the motivation of club members by considering personal characteristics and implementing an individual approach; d) consider the head of the club association as a bearer of cross-cultural competence and equip them with interactive technologies of leisure, educational, and cultural activities, allowing realizing this potential.

Authors' Contributions: Zalutskaya, S. Y.: conception and design, acquisition of data, analysis and interpretation of data, drafting the article, critical review of important intellectual content. The author has read and approved the final version of the manuscript.

Ethics Approval: Not applicable.

Acknowledgments: The article was funded by a grant from the Ministry of Education of the RF in the form of subsidies for the implementation of measures aimed at the full functioning and development of the Russian language, the departmental target program "Scientific-methodological, methodological and staffing support for teaching the Russian language and the languages of the peoples of the RF" subprogram "Improving the management of the education system" state program of the RF "Development of education" (Agreement No. 073-15-2020-2637).

\section{REFERENCES}

Aksenova, G. I. (2020). Yazykovoi klub kak effektivnyi sposob vkhozhdeniya v inokulturnuyu sredu [A language club as an efficient way of entering a foreign cultural environment]. Yazyki i literatura v polikulturnom prostranstve, 6, 5-10.

Anderson, J., \& Guan, Y. (2017). Implicit Acculturation and the Academic Adjustment of Chinese Student Sojourners in Australia. Australian Psychologist, 53(3), 1-9. https://doi.org/10.1111/ap.12332

Brito, R. S., Prado, J. R., \& Nunes, C. P. (2017). As condições de trabalho docente e o pós-estado de bem-estar social. Revista Tempos e Espaços em Educação, 10(23), 165-174. https://doi.org/10.20952/revtee.v10i23.6676

Bukhtiarova, E. Yu. (2020). Novye tekhnologii v sisteme nepreryvnogo dopolnitelnogo obrazovaniya v professionalnom razvitii pedagoga [New technologies in the system of continuous additional education in the pedagogue's professional development]. Mir nauki, kultury i obrazovaniya, 5(84), 17-19. https://doi.org/10.24411/1991-5497-2020-00856

Cgtn. (2019). Why China can give every child equal access to education. Available:

https://news.cgtn.com/news/3d3d514f7851444d35457a6333566d54/index.html

Dergaeva, S. S. (2017). Dopolnitelnoe yazykovoe obrazovanie. Klub angliiskogo yazyka [Additional linguistic education. English language club]. Alma mater (Vestnik vysshei shkoly), 7, 112-117.

Druzhinina, R. V. (2018). O putyakh razvitiya professionalno znachimykh umenii studentov pri obuchenii inostrannomu yazyku v programmakh podgotovki menedzherov [Ways of developing professionally significant skills of students when teaching a foreign language in manager training programs]. Inostrannye yazyki: lingvisticheskie i metodicheskie aspekty, 41, 26-31. 
Khlystov, Y. (2016). Chinese education: students, teachers, and methodology. Laowaicareer. Available: https://www.laowaicareer.com/blog/chinese-pop-culture-every-teacher-know/

Machekhina, O. N. (2017). Srednyaya shkola v Yaponii [Middle school in Japan]. Pedagogicheskii zhurnal Bashkortostana, 1(68), 37-44.

Novikov, A. M. (2006). Formy obucheniya v sovremennykh usloviyakh [Forms of education in the modern conditions]. Spetsialist, 1, 27-31.

Shapovalova, P. V. (2014). Klubnaya forma organizatsii obucheniya kak naibolee effektivnyi metod formirovaniya lingvokulturnoi kompetentsii [Club-based form of organizing education as the most efficient method of forming the linguocultural competence]. In: Malysheva, N. V. (Ed.). Ammosov-2014: collected proceedings of the all-Russian scientific and practical conference within the framework of the Forum of the Scientific Youth of Federal Universities, Ammosov NEFU, September 15-19, 2014, Yakutsk, Russia. Kirov: International Center for Research Projects, pp. 722728.

Silva, L. R., Santos, A. R., \& Santos, I. T. R. (2020). Public policies for education of/in the field and the school environment in a settlement of the MST: the intimate relationship with the pedagogical policy. Journal of Research and Knowledge Spreading, 1(1), e11737. http://dx.doi.org/10.20952/jrks1111737

Tanikawa, M. (2003). Free to Be. The New York Times. Available: https://www.nytimes.com/2003/01/12/education/free-to-be.html

Torshina, A. V. (2017). Evolyutsiya ponyatiya "klubnaya deyatelnost" v istoriko-pedagogicheskom protsesse [Evolution of the notion "club activity" in the historical and pedagogical process]. In: Kaynova, G. A., Akhmetov, I. G. (Eds.). Aspekty i tendentsii pedagogicheskoi nauki: proceedings of the 2nd International scientific conference, July 20-23, 2017, St. Petersburg, Russia. St. Petersburg: Svoe izdatelstvo, pp. 10-13. Available: https://moluch.ru/conf/ped/archive/216/12645/

Tregub, T. V. (2017). Teatralizovannyi spektakl na inostrannom yazyke dlya podrostkov v ramkakh tvorcheskoi masterskoi yazykovogo kluba. Analiz effektivnosti uchebnogo i motivatsionnogo komponentov [Theatrical play in a foreign language for teenagers within the framework of the creative workshop of a language club. Analyzing the efficiency of the educational and motivational components]. Sovremennye tendentsii razvitiya nauki i tekhnologii, 1-8, 145-149.

Zhu, J. (2016). Chinese Overseas Students and Intercultural Learning Environments. Academic Adjustment, Adaptation and Experience. London: Palgrave Macmillan, $259 \mathrm{p}$.

Received: 15 January 2021 | Accepted: 2 April 2021 | Published: 25 April 2021 